Review

\title{
Epigenetic Regulation in Etiology of Type 1 Diabetes Mellitus
}

\author{
Marie Cerna \\ Department of Medical Genetics, Third Faculty of Medicine, Charles University, Ruska 87, 10000 Prague 10, \\ Czech Republic; marie.cerna@lf3.cuni.cz; Tel.: +420-267102491
}

Received: 25 November 2019; Accepted: 17 December 2019; Published: 19 December 2019

\begin{abstract}
Type 1 diabetes mellitus (T1DM) is caused by an autoimmune destruction of the pancreatic $\beta$-cells, a process in which autoreactive T cells play a pivotal role, an $\mathrm{d}$ it is characterized by islet autoantibodies. Consequent hyperglycemia is requiring lifelong insulin replacement therapy. T1DM is caused by the interaction of multiple environmental an $d$ genetic factors. The integrations of environments an $d$ genes occur via epigenetic regulations of the genome, which allow adaptation of organism to changing life conditions by alternation of gene expression. T1DM has increased several-fold over the past half century. Such a short time indicates involvement of environment factors an d excludes genetic changes. This review summarizes the most current knowledge of epigenetic changes in that process leading to autoimmune diabetes mellitus.
\end{abstract}

Keywords: epigenetic modifications; type 1 diabetes; HLA class II; insulin

\section{Introduction}

Type 1 diabetes mellitus (T1DM) belongs to severe chronic autoimmune disorders, where mediators of autoimmune process are activated T lymphocytes, which attack pancreatic $\beta$-cells, because they recognize their autoantigens. For clinical manifestation it is necessary to destroy more than $70 \%$ tissues producing insulin. T1DM is considered to be a genetic disease with complex multifactorial heredity, since its predisposition is determined by the interaction of risk, protective an d neutral alleles of approximately 50 genes together with environment. The re are three main chromosomal regions that are reproducibly an d statistically significantly associated with T1DM: the region of human leukocyte an tigen (HLA) on chromosome 6p21, the gene for protein tyrosin-phosphatase non-receptor-type 22 (PTPN22) on chromosome 1p13, an d the region of insulin (INS) gene on chromosome 11p15 [1,2].

\subsection{HLA Class II Alleles as a Main Predisposition Genetic Factor in T1DM}

HLA class II molecules are essential in the adaptive immune response. In the thymus, they participate in the selection of $\mathrm{T}$ cell repertoire. In the periphery, they present peptides on the surface of an tigen presenting cells (APC) to the receptors of CD4+ T cells [3]. HLA class II molecules include three isotypes: HLA-DR, HLA-DQ, an d HLA-DP. Each of them consists of two transmembrane chains, alpha an $d$ beta. The ir extracellular parts form a peptide-binding site. HLA-DQ, particularly the alleles DQB1*02:01 an d DQB1*03:02 coding for its beta chain, is the most significant predisposition molecule for T1DM. Contrary to this, HLA-DQB1*06:02 is associated with the dominant protection against T1DM. Many an alyses have proved that DQB1*0302 allele is the strongest susceptibility genetic factor an $d$ that the heterozygous combination of HLA-DR4-DQA1*0301-DQB1*0302 an $d$ HLA-DR3-DQA1*0501-DQB1*0201 haplotypes results in a synergistically increased predisposition to T1DM [4]. 


\subsection{Environmental Risk Factors in T1DM}

Environmental risk factors are long known as a pivotal trigger of $\beta$-cell destruction (Figure 1 ). Early epidemiological studies have discussed viral infections as a potential cause of T1DM. The strongest candidate seems to be enteroviruses that are detected in the pancreas of T1DM patients [5].

Dietary factors involve a protective role of breastfeeding that provide passive an $\mathrm{d}$ active immunization for infants, on one side, an $\mathrm{d}$ on an other side, a predisposition role of early exposure to cows' milk an d solid foods (fruit, root vegetables, gluten an d non-gluten containing cereals, eggs). The se risk factors support the hypothesis that general an tigenic stimulations are more important than an actual an tigen in disease process. The se associations may be owing to immature immune response an $\mathrm{d}$ insufficient tolerance in the gut [5]. Moreover, a relative deficiency of long-chain polyunsaturated fatty acids (e.g., omega-3 fatty acids), typically in many western diets, can predispose to inflammation. It should be also mentioned that toxins (chemicals or mycotoxins) in foods or water may activate autoimmune reactions [5].

A tight relationship exists between the gut microbiome an $d$ the immune system. The multiple microbiota promote the development of the immune system from the gestation period to the infancy an d early childhood, particularly in the concept of induction of immune tolerance. In this context, a microbiome imbalance can cause autoreactivity in genetically susceptible individuals [6].

A lot of investigation has been made about the hygiene hypothesis. This hypothesis supposes that the increased incidence of allergic an d autoimmune diseases reflects the decrease in overall infection frequency due to improved hygiene an d introduction of an tibiotics in industrialized countries in last century. Commensal microorganisms an d parasites protect against a variety of autoimmune conditions by nonspecific allo-stimulation of innate immunity [7].

Last but not least, among environmental factors, the important point has psychological stress. Serious life events (divorce or death in the family) can activate the hypothalamic-pituitary-adrenal (HPA) axis or the nervous system, both influence the immune cells an d increase insulin resistance [8]. Furthermore, endoplasmic reticulum stress increases abnormal post-translational modification of $\beta$-cell proteins an $\mathrm{d}$ by this way promotes generation of autoantigens.

\subsection{Epigenetic Regulations as a Connection between Environment and Genome}

Multifactorial heredity represents multiple epistasis model of inheritance, where susceptibility to certain pathological symptom is given by specific combination of multiple gene loci. Environment factors act on predisposition genes an $\mathrm{d}$ are necessary for outburst of disease. The integrations of internal hormonal an d external surrounding environments occur via epigenetic regulations of our genome, which allow adaptation of organism to changing life conditions by alternation of gene activity, by modifying gene expression. Epigenome, in fact, controls accessibility of DNA for transcription factors that regulate level of gene expression. In other words, epigenetic modifications are consequences of environment interactions with identical genotypes that result in formation of their various phenotypes [9].

Epigenetic regulations represent modifications of gene expression which do not involve nucleotide changes, but can be heritable. Main epigenetic mechanisms include DNA methylation, post-translational histone modifications, an d RNA-mediated gene silencing. The se epigenetic modifications are closely linked an d often influence each other [10,11]. Epigenetic regulations are essential for cell differentiation, development, an d protection against viruses. The y are critical for the integration of endogenous an d environmental signals during the life [12-14]. Dysregulations of epigenetic mechanisms have been associated with a number of age related disorders including cancers an d autoimmunity $[15,16]$. 


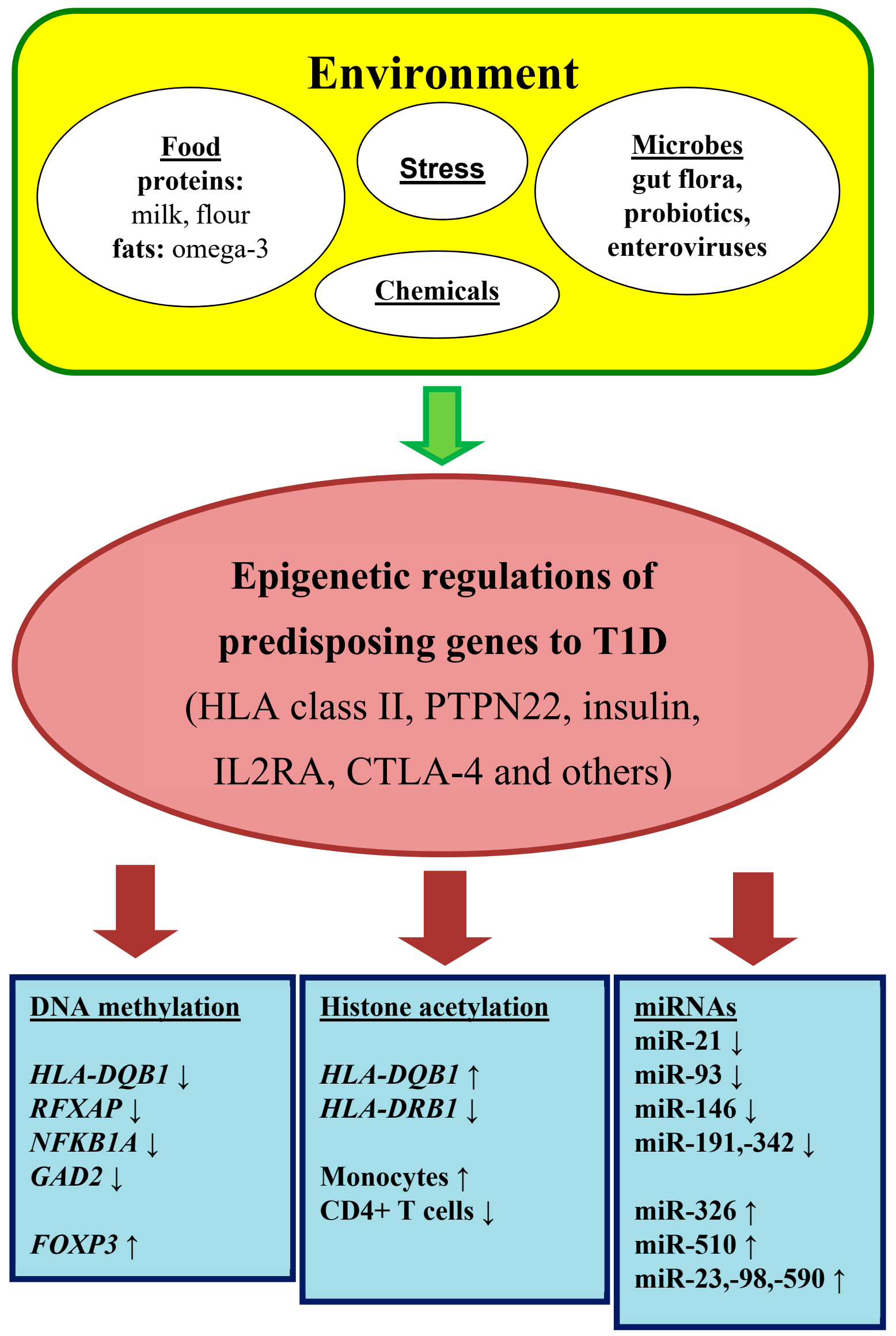

Figure 1. Epigenetic regulation in autoimmune diabetes mellitus. 
A distinguishing feature of epigenetic changes in comparison with genetic changes is that they tend to be acquired in a gradual rather than an abrupt process. For example, under physiological conditions cells an d tissues show a progressive loss of DNA methylation, primarily within the repeated sequences, but also in potential gene regulatory areas. In parallel, under pathological conditions cells an $\mathrm{d}$ tissues show progressive increases in promoter methylation of selected genes, which lead to permanently gene expression silencing. The se changes are highly mosaic in a given tissue an $\mathrm{d}$ insert a high degree of epigenetic variability between cells [17]. Such epigenetic modifications could alter immune response by masking/unmasking potential an tigens an $\mathrm{d}$ by modulating immune reactions of effector cells [18].

\section{DNA Methylation an d Its Role in T1DM}

DNA undergoes attachment of the methyl group on the fifth carbon of cytosine, creating a 5-methylcytosine (Figure 2), preferentially in the CpG dinucleotides. This CpG sequence is palindromic; it is present on both strands [19]. The methyl group is transferred from the S-adenosyl methionine donor (SAM) to the DNA. This transfer is carried out by DNA-methyltransferase enzymes (DNMTs).

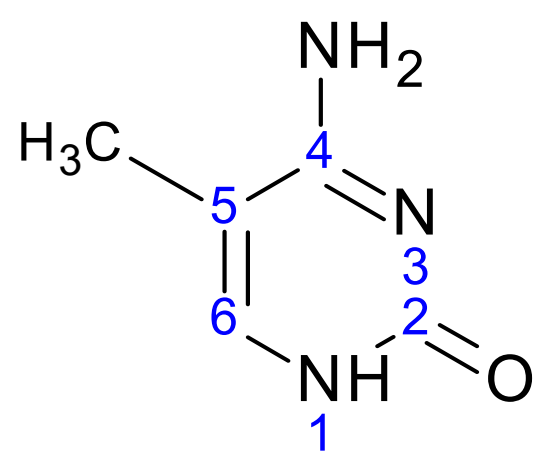

5-methylcytosine

Figure 2. The basic structural element of DNA modification: 5-methylcytosine.

Most CpG dinucleotides in mammalian genome are methylated. Effect of DNA methylation depends on its position in genes, but in both, in gene regulatory regions as well as in gene bodies, is important for regulation of their expression [19]. Methylation in the gene body decreases ability of RNA polymerase to transcribe a gene on the level of RNA polymerase binding, transcription initiation an d elongation. For regulation of transcription initiation, the most important is methylation located in the regulatory region (in a promoter or a first intron) of the gene. Promoter methylation is generally associated with gene silencing an $d$ the mechanism of the association can be described by two non-exclusive models: (1) Methyl group directly blocks an access of transcriptional coactivators to their cognate sequences, an d (2) 5-methyl-CpG is recognized by methyl-CpG-binding proteins (MBD) that induce repressive state of chromatin. In this case, it is plausible that the strength of the effect could depend on the local concentration of methylated cytosines.

Weber et al. divided gene promoters into three categories according to their C, G, an d CpG density. The y studied effect of promoter DNA methylation on gene expression. Promoters with low CpG density were common among tissue-specific genes, an d were mostly methylated without an y relationship to the gene activity. Promoters with high $\mathrm{CpG}$ density were more frequently found with housekeeping genes, an d were usually non-methylated irrespective of the promoter activity. Promoters with intermediate $\mathrm{CpG}$ density were intermediary methylated, an d promoter methylation correlated with gene expression. The high an d intermediate DNA methylation of promoters represses gene expression [20]. 
However, an other team did not observe a positive correlation between the promoter methylation an $\mathrm{d}$ the gene transcription across an y type of promoters [21].

According to criteria of the study above, HLA DQA1 an d DQB1 gene promoters belong among low-CpG promoters, which should be methylated an $\mathrm{d}$ their methylation should not be an obstacle to the allele expression. However, nonmethylated CpG positions are near to the beginning of transcription, where SXY boxes binding transcription factors are located. It was published that methylation in this region leads to suppression of transcription, for instance, in tumor cells [22]. A CpG rich region is located in the intron 1 of DQB1 gene, an d this might be able to suppress transcription [23].

\subsection{Monozygotic Twin Studies}

T1D disease-association studies employ monozygotic (MZ) twins discordant for the disease to investigate the effect of non-genetic factors on the disease development [24]. Rakyan et al. generated genome-wide DNA methylation profiles of purified CD14+ monocytes from 15 T1DM-discordant $\mathrm{MZ}$ twin pairs. Monocytes are immune effector cells that give rise to tissue macrophages that have been associated with the destruction of the islet cells, causing insulin deficiency. The y identified 132 T1DM-associated methylation variable positions (of them 58 were hypermethylated an $\mathrm{d} 74$ were hypomethylated). The se included hypomethylation of HLA class II gene, $H L A-D Q B 1$, which carries the highest single genetic risk for T1DM (along with HLA-DRB1), hypomethylation of RFXAP, an HLA class II regulating element, hypomethylation of NFKB1A, an important regulator of apoptosis an $\mathrm{d}$ inflammatory immune responses, an d hypomethylation of GAD2 which encodes GAD65, a major T1DM autoantigen involved in disease etiology. Authors also demonstrated that T1DM-associated methylation variable positions precede clinical diagnosis, an $\mathrm{d}$ are temporally stable over many years [25].

Stefan et al. performed genome-wide DNA methylation profiles in B cell lines from $3 \mathrm{MZ}$ twin pairs discordant for T1DM an d $6 \mathrm{MZ}$ twin pairs concordant for the disease. The y identified $88 \mathrm{CpG}$ sites (of them 55 were hypermethylated an d 33 were hypomethylated) displaying significant methylation changes in all T1DM-discordant MZ twin pairs, including hypermethylation of HLA-DOB an $\mathrm{d} H L A-D Q A 2$ genes in patients [26].

Elboudwarej et al. provided genome-wide DNA methylation profiles in peripheral blood from 7 T1D-discordant MZ twin pairs. Strong evidence for global hypomethylation of CpG sites within promoter regions in MZ twins with TIDM compared to twins without T1DM was observed [27].

There were presented a large epigenome-wide association study across 406,365 CpGs in $52 \mathrm{MZ}$ twin pairs discordant for T1DM in three immune effector cell types, CD4+ T cells, CD19+ B cells an d CD14+CD16- monocytes. Authors observed a substantial enrichment of differentially variable CpG positions in T1DM twins when compared with their healthy co-twins an d when compared with healthy, unrelated individuals. The se T1DM-associated differentially variable CpG positions were found to be temporally stable an d enriched at gene regulatory elements. Evidence from cord blood of newborns who progress to overt T1DM suggested that the differentially variable CpG positions likely emerged after birth. Integration with cell type-specific gene regulatory circuits highlighted pathways involved in immune cell metabolism an d the cell cycle (particularly in CD19+ B cells, there were found transcriptional regulators such as NRF1 an d FOXP1 an d pathways such as mTOR signaling). Consequently, authors overlapped these T1DM-associated differentially variable CpG positions with 59 T1DM genetic susceptibility loci retrieved from T1DM base, an $d$ they did not find a statistically significant enrichment of differentially variable $\mathrm{CpG}$ positions at these loci. This an alysis provided further evidence that T1DM-associated genetic an d epigenetic variants have appeared to act independently [28].

The association between DNA methylation an d T1DM is supported by observation that methylation status of CD14+ monocytes an d CD4+ T cells of a prediabetic quadruplet was intermediate between its affected an d healthy siblings, suggesting a relationship between disease severity an $\mathrm{d}$ DNA methylation [29]. 
The comparison of DNA methylation of the HLA-DQA1 gene between HLA-matched T1DM patients an $\mathrm{d}$ healthy unrelated controls in our laboratory revealed no difference in DNA methylation of the proximal promoter of this gene. However, for the first time, the complete methylation profile of the HLA-DQA1 promoter was gained with the most methylated allele DQA1*02:01 an $d$ the least methylated DQA1*05:01 in both studied groups [30,31].

\subsection{The Decrease of Immune Tolerance is Regulated by DNA Methylation}

Many studies have implicated defects of immunological tolerance in the onset an d progression of autoimmune disease, such as T1DM. Well-known immunoregulators that can suppress the proliferation of effector cells are regulatory $\mathrm{T}$ cells (Tregs). Tregs are a unique population of CD4+, CD25+ T cells that express the "forkhead box P3" transcription factor (FOXP3).

Epidemiological studies suggest that latent autoimmune diabetes in adults (LADA) may account for $2-12 \%$ of all cases of diabetes. The presence of autoantibodies along with islet-reactive $\mathrm{T}$ cells in LADA provides strong evidence that the disease process is autoimmune. LADA is thought to be a subgroup of type 1 diabetes, which has a slow procession of autoimmune destruction of $\beta$-cells. It was observed that genomic DNA methylation in CD4+ T cells from LADA patients was significantly increased compared to controls, an d the FOXP3 promoter region was hypermethylated in CD4+ T cells from LADA patients compared with controls. Subsequently, it was proved at the level of mRNA that FOXP3 expression was decreased in diabetic patients [32].

\subsection{Insulin Gene and Its Epigenetic Modifications}

The insulin (INS) region is the second most important locus associated with T1DM. Many studies have been consistently confirmed that T1DM is associated with the A/T single nucleotide polymorphism (SNP) called rs689 an d located in the intron 1, at position $+215 \mathrm{bp}$ distal to the transcriptional start site of the INS gene. Proximal to rs689 an d in complete linkage disequilibrium with it, there is located the variable number tandem repeat (VNTR) polymorphism, which is divided into three classes. In Caucasians, SNP allele A is associated with short class I VNTR alleles, more frequent in T1DM, while SNP allele T is associated with long class III VNTR alleles. Studies of INS gene expression suggested that while class I alleles are associated with increased INS expression in the human pancreas versus class III alleles, the opposite observation has been obtained in the thymic tissue. Decreased INS expression of class I alleles in the thymus could lead to worse negative selection of autoreactive $\mathrm{T}$ cells, an d then higher predisposition to autoimmunity. The variation of DNA methylation within the INS gene promoter is suspected to regulate INS gene transcription in the pancreatic $\beta$-cells an $\mathrm{d}$ the medullary thymic epithelial cells, the two tissues that express this gene an $\mathrm{d}$ are central to the mechanisms of T1DM [33].

The study of DNA methylation pattern of the 7 CpGs in the INS gene promoter revealed that T1DM patients have a lower methylation at CpGs $-19,-135$, an $\mathrm{d}-234\left(p=2.10^{-16}\right)$ an $\mathrm{d}$ a higher methylation at CpG -180 than controls, while methylation was comparable at CpGs $-69,-102,-206$. The magnitude of the hypomethylation relative to a control population was $8-15 \%$ of the corresponding levels in controls [34].

One study highlighted the cross talk between immune responses an $\mathrm{d} \beta$-cell specific DNA methylation changes at Ins1 an $\mathrm{d}$ Ins 2 in islets from non-obese diabetic mice (NOD) mice, an d in human $\beta$-cells in vitro. In the NOD mouse model of T1DM, inflammatory cytokines including TNF, IFN $\gamma$, IL6 an $\mathrm{d}$ IL1B increase with age. Authors showed reduced insulin gene expression an d increased percent DNA methylation at exon 2 of Ins1 an d exon 1 of Ins 2 genes in sorted $\beta$-cells from 4 week-old NOD mice cultured in media with cytokines. Moreover, increased cytokines induced mRNA expression levels of DNMTs in sorted $\beta$-cells of cultured islets from NOD mice an d from human non-diabetic donors. This study suggests that increased cytokine levels associated with T1DM induce increased DNA methylation an d decreased insulin mRNA levels in islets [35]. 
There was interest in quantifying the amount unmethylated preproinsulin DNA in the circulation as a biomarker of $\beta$-cells death. The $\beta$-cells have a much higher frequency of unmethylated CpG sites within the preproinsulin gene than other cells, an $\mathrm{d}$ upon $\beta$-cell death these DNA sequences are released into the circulation [36]. Studies were found increased levels of unmethylated preproinsulin DNA in peripheral blood samples of patients with new-onset T1DM compared with controls [37,38]. However, although this hypothesis has been disputed, circulating demethylated amylin DNA has seemed to be a valid biomarker for $\beta$-cell death in T1DM [39].

\subsection{Interleukin 2 Receptor $\alpha$-Chain Gene an $d$ Its Epigenetic Modifications}

Interleukin 2 receptor $\alpha$-chain $(I L 2 R A)$, or CD25 molecule, is part of the high-affinity IL-2 receptor complex. IL2RA is expressed constitutively on regulatory T cells, a population of $\mathrm{T}$ cells that have a potent ability to suppress autoreactive $\mathrm{T}$ cells, whereas is induced in other $\mathrm{T}$ cells. IL-2RA polymorphisms are associated with T1DM an d other autoimmune diseases such as multiple sclerosis or rheumatoid arthritis.

The study of DNA methylation pattern of the $6 \mathrm{CpGs}$ in the IL2RA gene promoter revealed that T1DM patients have a higher level of methylation at CpGs -373 an $\mathrm{d}-456$ than controls $\left(p=1.10^{-4}\right.$ an $\mathrm{d} p=2 \cdot 10^{-6}$ respectively). Moreover, among SNPs located in the neighboring region, it was found that twenty-eight SNPs were associated with DNA methylation at CpG -373, an d sixteen of these SNPs were known to be associated with T1DM. The se findings suggest that the effect of IL2RA risk alleles on T1DM may be partially mediated through epigenetic changes [40].

\subsection{The Intestinal Microbiome an d Epigenome in T1DM}

The fetus gut is sterile. Its colonization of microbes starts at birth, an $\mathrm{d}$ includes maternal microbiota of genital tract an d colon. In neonates, the species of intestinal microbiota are not too much divergent, but they enlarge an d diverge in the next two years, an d remains constant through all life [41].

It was observed that the gut microbiome of individuals, before or after manifestation of diabetes mellitus, is different from that of healthy individuals. The intestinal microbiota in patients with preclinical T1DM is characterized by Bacteroidetes phylum, a lower quantity of butyrate-producing bacteria, reduced bacterial diversity, an d community instability. The se changes emerge after the positivity to autoantibodies that are predictive for T1DM. The gut microbiota could be involved in the progression from asymptomatic autoimmunity to its clinical manifestation rather than in the initiation of $\beta$-cell destruction [42].

Butyrate is one of the short-chain fatty acids (others are acetate an d propionate) produced by bacterial fermentation in the gut. Butyrate is known to play an important role in maintaining the integrity of the epithelial layer. The re is also increasing evidence that butyrate has epigenetic effects that may be very important in T1DM, where their deficiency leads to disease manifestation. Butyrate induces the methylation of promoter regions, which causes both up- an d downregulation in different sets of human genes. Histone acetylation also appears to be regulated by butyrate production. Butyrate reduces lipopolysaccharide-induced inflammation in the intestine through modulation of an tioxidant defense systems, nitric oxide production, an d expression of inflammatory cytokines [43]. See the summary about DNA methylation in Table 1. 
Table 1. The epigenetic changes found in patients with T1DM: DNA methylation.

\begin{tabular}{cccc}
\hline $\begin{array}{c}\text { Publication } \\
\text { (1st Author + Year) }\end{array}$ & Specific Target & Type of Cells & Results \\
\hline $\begin{array}{c}\text { Rakyan, 2011 [25] } \\
\text { (MZ twins) }\end{array}$ & genome-wide profile & CD14+ monocytes & $\begin{array}{c}\downarrow H L A-D Q B 1, R F X A P \\
\text { NFKB1, AGAD2 }\end{array}$ \\
\hline $\begin{array}{c}\text { Stefan, 2014 [26] } \\
\text { (MZ twins) }\end{array}$ & genome-wide profile & B cell lines & $\uparrow$ HLA-DOB + HLA-DQA2 \\
\hline $\begin{array}{c}\text { Elboudwarej, 2016 [27] } \\
\text { (MZ twins) }\end{array}$ & genome-wide profile & peripheral blood & global hypomethylation \\
\hline $\begin{array}{c}\text { Paul, 2016 [28] } \\
\text { (MZ twins) }\end{array}$ & genome-wide profile & $\begin{array}{c}\text { CD4+ T cells } \\
\text { CD19+ B cells } \\
\text { CD14+ monocytes }\end{array}$ & $\begin{array}{c}\text { long time stable variabilities } \\
\text { in regulatory regions }\end{array}$ \\
\hline $\begin{array}{c}\text { Disanto, 2013 [29] } \\
\text { (MZ quadruplet) }\end{array}$ & genome-wide profile & $\begin{array}{c}\text { CD14+ monocytes } \\
\text { CD4+ T cells }\end{array}$ & $\begin{array}{c}\text { association with severity } \\
\text { of disease }\end{array}$ \\
\hline $\begin{array}{c}\text { Cepek, 2016 [31] } \\
\text { Li, 2011 [32] }\end{array}$ & HLA-DQA1 gene & $\begin{array}{c}\text { peripheral blood } \\
\text { CD14+ monocytes }\end{array}$ & $\begin{array}{c}\text { no differences between } \\
\text { patients versus healthies }\end{array}$ \\
\hline Fradin, 2012 [34] & INS gene promoter & leucocytes & $\uparrow$ FOXP3 \\
\hline Belot, 2013 [40] & IL2RA gene promoter & peripheral blood & 2 CpG variabilities (both $\uparrow)$ \\
\hline$\downarrow$ Decrease of DNA methylation (hypomethylation). $\uparrow$ Increase of DNA methylation (hypermethylation).
\end{tabular}

\section{Histone Modifications an d Their Role in T1DM}

Histones undergo post-translational modifications on the specific amino acid residues in the $\mathrm{N}$-terminal part of the histone. The significance of modifications is determined by the type of modification (acetylation, methylation, phosphorylation, ubiquitination, an $\mathrm{d}$ more), the position in the nucleosome (modified residue on the histone) an d the degree of modification (e.g., mono-, di-, an $\mathrm{d}$ trimethylation). The certain modification is specifically recognized by chromatin-remodeling proteins that subsequently change the level of chromatin condensation. The resulting effect on the level of gene expression depends on the region of modifications (gene promoter, gene body, enhancer, an $\mathrm{d}$ CpG islets), the combination of modifications an $\mathrm{d}$ the pattern of modifications [17].

Histone acetylation, particularly histones $\mathrm{H} 3$ an $\mathrm{d} \mathrm{H} 4$, is an important marker of transcription activation, because it brings a negative charge an $\mathrm{d}$ so keeps away the negatively charged DNA molecule. Lower chromatin condensation forms a space for the transcription complex. Acetylation is reversible, an $\mathrm{d}$ it is performed on lysine residue. All process is controlled by histone-acetyltransferases (HATs) an d histone-deacetylases (HDACs), which function as the transcription co-activators, HAT, an $\mathrm{d}$ the transcription corepressors, HDAC, respectively. Acetylation of histones is a result of the balance between the activity of HAT an d HDAC. Removal of the acetyl group causes chromatin condensation an d transcription repression. A low level of acetylation can induce further histone modifications an d DNA methylation. A high level of acetylation protects DNA from methylation, an d reversely, DNA methylation prevents histone acetylation [9].

Histone methylation is performed on lysine or arginine residues, an d includes the addition of one to three methyl groups. Histone methylation is associated with both, transcription activation or repression, depending on the gene region an d extent level of modification. Monomethylation or trimethylation of lysine 4 of the histone 3 (H3K4me1 or H3K4me3) is associated with active promoters. On other side, trimethylation of lysine 9 an d 27 of the histone 3 (H3K9me3 an d H3K27me3) is associated with gene silencing an $\mathrm{d}$ compacted chromatin. The re is closed relationship between the methylation status of lysine 4 an d lysine 9 on the histone H3 (H3K4 an d H3K9) an d DNA methylation. The DNA methylation is linked to the absence of H3K4 methylation an d the presence of H3K9 methylation [10].

The main linkage of histone methylation with DNA methylation are DNMT proteins (Figure 3) that specifically interact with the N-terminus of $\mathrm{H} 3$, but only if it is unmethylated. Thus, they act as a 
H3K4 methylation sensor that an $\mathrm{d}$ in the absence of $\mathrm{H} 3$ methylation induces de novo methylation of DNA. The link of H3K9 methylation with DNA methylation is mediated by UHRF protein which binds DNMTs an d brings them to DNA [44].

Histone methylation

0 DNA methylation
H3K4 - lysine 4 of the histone 3

H3K9 - lysine 9 of the histone 3

DNMT - DNA-methyltransferase

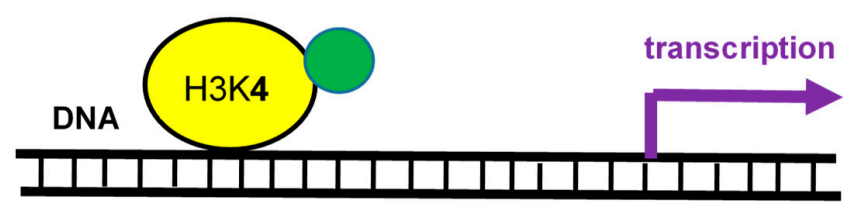

promoter

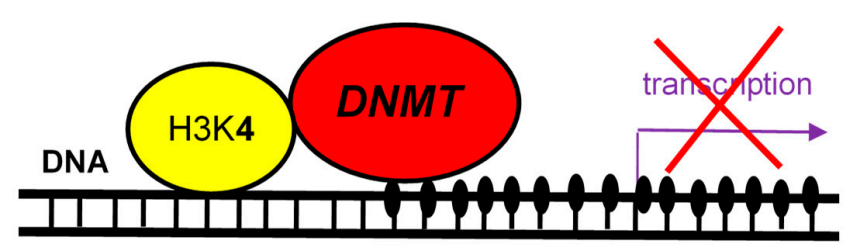

promoter

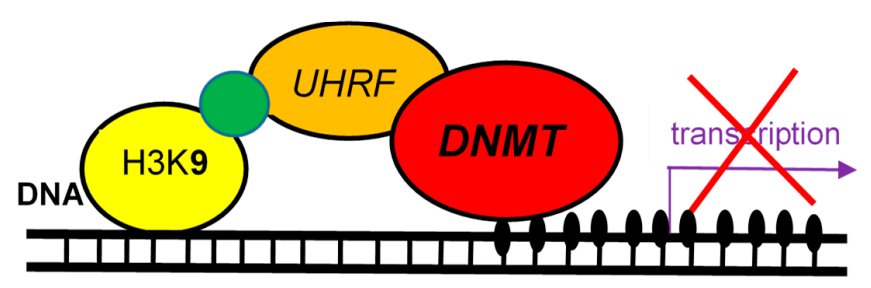

promoter

Figure 3. Interactions between histone methylation an d DNA methylation.

The significant link between histone modifications an d HLA class II expression is presented by a transcriptional coactivator Class II transactivator (CIITA). This regulatory protein not only associates with HATs, but also acts as one itself. The importance of its role in epigenetic regulation is underlined 
by the fact that HLA II genes can be induced by HDAC inhibitor Trichostatin A (TSA) even in the absence of CIITA [45].

\subsection{The Studies of Natarajan's Group}

Histone modifications in T1DM were explored by a set of works by Miao. The authors observed differences in various histone modifications (H3K9Ac, H4K16Ac, H3K4me3, H3K9me2,3, H3K27me3) of genes involved in diabetes pathways between T1DM an $\mathrm{d}$ healthy controls [46,47]. The loci of variant chromatin modifications were also located close to DQB1 an d DRB1 genes: Monocytes from T1DM patients had lower levels of H3K9Ac $4 \mathrm{~kb}$ upstream of HLA-DRB1 an d higher levels of H3K9Ac $4 \mathrm{~kb}$ upstream of HLA-DQB1 [47]. The increased acetylation at these sites correlates with increased transcription in the monocyte cell line [47]. However, it is not possible to decide whether the differences are a cause of the disease or result of the disease-associated hyperglycemia [48,49]. In addition, authors do not state whether the patients an d controls were HLA-matched or not, so we cannot exclude the option that the observations are result of interallelic variation rather than a disease.

\subsection{The Role of Innate Immunity}

The study of inflammatory mediators, such as COX-2, in monocytes found that acetylated histone H4 expression was increased in T1DM patients compared with control subjects. COX-2 levels did not seem to follow the histone acetylation pattern, indicating that its induction may not be related to the hyperacetylation. When the diabetic group was divided into two groups on the basis of pre-diagnosed vascular complications, the histone hyperacetylation was restricted to the complication-free group, indicating that it is not associated with diabetic complications [50].

\subsection{The Decrease of Immune Tolerance is Regulated by Histone Acetylation}

Similarly to the publication on DNA methylation in CD4+ T cells from LADA patients, an other study was explored whether the histone acetylation of CD4+ T cells is involved in the pathogenesis an $\mathrm{d}$ development of LADA. In accordance with the observations of DNA methylation study, authors found the reduced global $\mathrm{H} 3$ acetylation in CD4+ T cells from LADA patients. The reduced $\mathrm{H} 3$ acetylation lever was associated with the positivity to GAD autoantibodies; the most important autoimmune marker of LADA. The expression of acetyltransferase CREBBP in LADA patients was downregulated an $\mathrm{d}$ the expression of histone deacetylases HDAC1 an $\mathrm{d}$ HDAC7 was upregulated. The y concluded that changes in $\mathrm{H} 3$ acetylation in CD4+ T cells possibly contributed to the pathogenesis of LADA [51]. Unfortunately, authors did not measure the FOXP3 expression an d promoter methylation status, so there is missing information about the proportion of Tregs. See the summary about histone modifications in Table 2.

Table 2. The epigenetic changes found in patients with T1DM: Histone modification.

\begin{tabular}{|c|c|c|c|}
\hline $\begin{array}{c}\text { Publication } \\
\text { (1st Author + Year) }\end{array}$ & Specific Target & Type of Cells & Results \\
\hline Miao, 2008 [46] & $\begin{array}{l}\text { genome-wide + } \\
\text { H3K9me2 }\end{array}$ & $\begin{array}{l}\text { monocytes } \\
\text { lymphocytes }\end{array}$ & $\begin{array}{c}\text { no differences } \\
\uparrow \mathrm{H} 3 \mathrm{~K} 9 \mathrm{me} 2\end{array}$ \\
\hline Miao, 2012 [47] & $\begin{array}{c}\text { T1DM susceptible loci } \\
\text { + H3K9Ac, H4K16Ac, } \\
\text { H3K4, H3K9, H3K27 me3 }\end{array}$ & $\begin{array}{l}\text { monocytes } \\
\text { lymphocytes }\end{array}$ & $\begin{array}{c}\text { differences in H3K9Ac: } \\
\uparrow H L A-D Q B 1, \downarrow H L A-D R B 1 \\
\text { no differences }\end{array}$ \\
\hline Chen, 2009 [50] & $\begin{array}{l}\text { genome-wide } \mathrm{H} 4 \\
\text { acetylation }\end{array}$ & monocytes & $\uparrow \mathrm{H} 4$ acetylation \\
\hline Liu, 2015 [51] & $\begin{array}{c}\text { genome-wide H3 } \\
\text { acetylation }\end{array}$ & CD4+ T cells & $\downarrow$ H3 acetylation \\
\hline
\end{tabular}

H3K9me2-dimethylation of lysine 9 of histone 3. H3K9Ac, H4K16Ac-acetylation of lysine 9 of histone 3, an d of lysine 16 of histone 4 . H3K4, H3K9, H3K27 me3-trimethylation of lysine 4, 9, an d 27 of histone 3 . $\downarrow$ Decrease of histone modification. $\uparrow$ Increase of histone modification. 


\section{RNA Interference an d Their Role in T1DM}

RNA interference denotes sequence-specific mRNA degradation induced by long double stranded RNA. It is an an cient eukaryotic defense mechanism against viruses an d mobile elements. In mammals, endogenous RNA interference was outstripped during evolution by the current innate an $d$ acquired immunity, but its apparatus, which remains essentially intact, serves mostly the silencing pathway, which regulates endogenous gene expression. The re are three well-defined RNA silencing pathways: microRNA (miRNA), small interfering RNA (siRNA), an d piRNA pathways [52].

In somatic cells, miRNAs are the most abundant an d functionally dominant small RNA class. During miRNA biogenesis (Figure 4), RNase III Dicer cleaves small hairpin precursors (pre-miRNAs) an d produces 21-23 nucleotides long miRNAs loaded on the RNA-induced silencing complex (RISC). The siRNA pathway shares protein components with the miRNA pathway; siRNAs contain also $\sim 22$ nucleotides, an $d$ it is produced by Dicer from long double stranded RNA. The experimental gene knock-down in mammalian cells relies on short RNAs—synthetic siRNAs or expressed miRNA.

The piRNA pathway operates in the germline. Substrates for the piRNA pathway are sense an $d$ an tisense transcripts from discrete genomic loci (piRNA clusters), which are produced by a complex, Dicer-independent mechanism. The piRNAs are longer than siRNAs or miRNAs (24-30 nucleotides).

The key component of RISC is an AGO protein from the Argonaute protein family (piRNAs are loaded onto Argonaute proteins from the PIWI subfamily). Mammals have four AGO proteins (AGO1-4). All AGO proteins bind miRNAs. AGO1, AGO3, an d AGO4 induce translational repression. Only AGO2 is capable of endonucleolytic cleavage of cognate RNAs, which is the hallmark of siRNAs. Some miRNAs loaded on AGO2 can induce endonucleolytic cleavage upon perfect base-pairing with targets. However, a typical miRNA binding is imperfect an d results in translational repression. By this way, miRNAs function as gene-specific inhibitors where miRNA networks provide a combinatorial system of post-transcriptional control of gene expression [53].

\subsection{The Decrease of Immune Tolerance is Regulated by miRNAs}

Genome-wide miRNA expression profiles of Tregs in T1DM patients described, in comparison with healthies, a significantly increased level of miR-510 an d decreased levels of miR-342 an d miR-191. Moreover, the miRNA comparison between Tregs an $\mathrm{d} T$ cells found a significant higher level of miR-146a an d lower level of eight specific miRNAs (20b, 31, 99a, 100, 125b, 151, 335, an d 365) in Tregs, supporting their involvement in T1DM [54].

Another group an alyzed the hypothesis that the failure to activate apoptosis produces uncontrolled expansion of autoreactive CD8 $+\mathrm{T}$ cells in diabetic patients. The y compared transcriptome an $\mathrm{d}$ corresponding miRNA expression with fate of autoreactive T cells from healthy an d T1DM individuals after their exposure to islet-autoantigen. Transcriptome an alysis described reduced expression of TRAIL, TRAIL-R2, FAS, an d FASLG (members of the extrinsic apoptosis pathway) in T cells derived from patients, compared with $\mathrm{T}$ cells derived from healthies. This finding was associated with increased expression of miRNAs that are predicted to regulate these genes, particularly miR-98, miR-23b, an $\mathrm{d}$ miR-590-5p [55].

\subsection{The Detection of miRNAs in Peripheral Blood Mononuclear Cells}

Sebastiani et al. found that miR-326 was significantly increased in peripheral blood lymphocytes from patients with T1DM an d the elevated levels correlated with disease severity. Furthermore, specific targets of miR-326 (vitamin D receptor, VDR, an d erythroblastosis virus E26 oncogene homolog 1, Ets1) are important immune regulators, potentially identifying pathways by which this miRNA may exert important stimulatory effects toward the development of T1DM [56]. Similar results had been observed in multiple sclerosis, in which miR-326 regulated Th-17 differentiation, an d its levels were highly correlated with disease severity [16]. 


\section{miRNA}

miRNA precursor
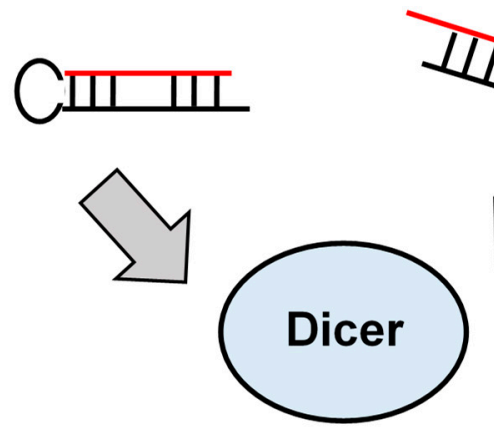

$\operatorname{miRNA}$
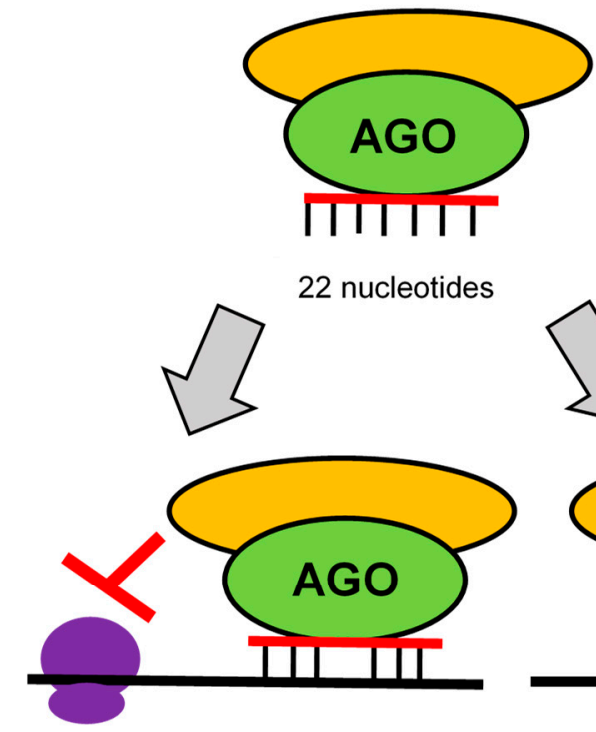

22 nucleotides

mRNA

inhibition of translation long dsRNA

siRNA

piRNA

antisense RNA

+ sense RNA

\section{पााााााााा

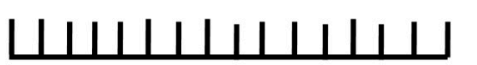

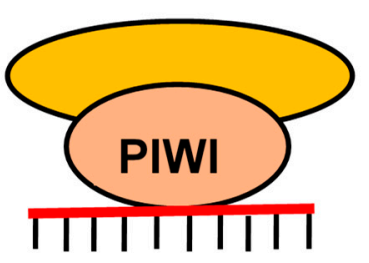

24-30 nucleotides
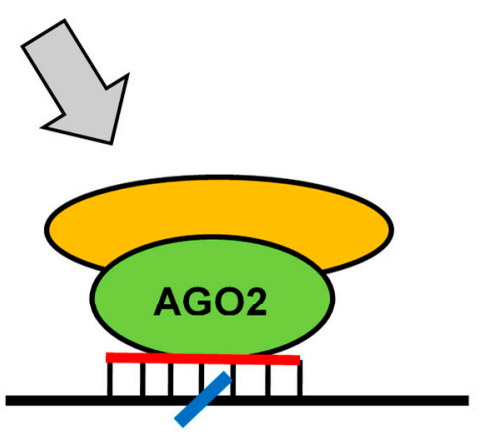

mRNA cleavage
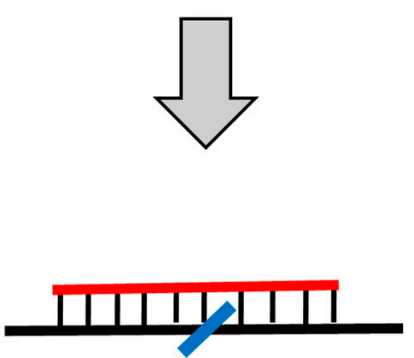

mRNA cleavage

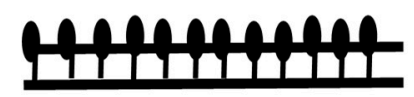

DNA methylation

Figure 4. Pathways of RNA interference.

Salas-Pérez et al. showed that miR-21a an d miR-93 are downregulated in peripheral blood mononuclear cells of T1DM patients [57]. The gene encoding the primary miR-21 (the primary transcript containing miR-21) is located within the intron region of the TMEM49 gene. Unlike other 
miRNAs, the function of miR-21 has been clarified to a large extent, its over-expression patterns in cancer have generally been well established, an d many of its bioinformatically predicted targets have been confirmed. Many publications have reported that miR-21 promotes Th17 cell differentiation, which mediates the development of multiple autoimmune diseases [58].

Yang et al. identified 26 miRNAs an d 1218 genes differently expressed in peripheral blood mononuclear cells from newly diagnosed T1DM patients. One of the most downregulated microRNAs in T1DM was miR-146, an d its expression level inversely correlated with the serum titers of GAD an tibodies [59].

\subsection{The Experimental Studies in Cultured Cells an $d$ Animal Models}

Many experimental studies in cultured cells an $\mathrm{d}$ an imal models of T1DM have provided convincing evidence that miRNAs can participate in controlling $\beta$-cell fate, autoimmune damage of $\beta$-cells, an $d$ regulation of insulin synthesis an $d$ secretion [60]. In mice, the disruption of miR-155 promoted the onset of T1DM an $\mathrm{d}$ a reduction of Treg cell number [61].

In NOD mice, Ruan et al. described a unique regulatory pathway of $\beta$-cell death that comprises miR-21, its target programmed cell death protein 4 (PDCD4), an d its upstream transcriptional activator nuclear factor-kB (NF-kB). In pancreatic $\beta$-cells, c-Rel an d p65 of the NF- $\mathrm{B}$ family activated the mir-21 gene promoter an d increased miR-21 RNA levels; miR-21 in turn decreased the level of PDCD4, which is able to induce cell death through the Bax family of apoptotic proteins. Consequently, PDCD4 deficiency in pancreatic $\beta$-cells renders them resistant to death. Thus, the NF- $\kappa \mathrm{B}-$ microRNA-21-PDCD4 axis plays a crucial role in T1DM an d represents a unique therapeutic target for treating the disease [62]. See the summary about RNA interference in Table 3.

Table 3. The epigenetic changes found in patients with T1DM: RNA interference.

\begin{tabular}{cccc}
\hline $\begin{array}{c}\text { Publication } \\
\text { (1st Author } \\
\text { Year) }\end{array}$ & Specific Target & Type of Cells & Results \\
\hline $\begin{array}{c}\text { Hezova, 2010 } \\
\text { [54] }\end{array}$ & genome-wide & Tregs & $\begin{array}{c}\text { i miR-510 } \\
\text { miR-342 + miR-191 }\end{array}$ \\
\hline $\begin{array}{c}\text { de Jong, 2016 } \\
\text { [55] }\end{array}$ & genome-target & CD8+ T cells & $\uparrow$ miR-98, miR-23b, miR-590 \\
\hline $\begin{array}{c}\text { Sebastiani, 2011 } \\
\text { [56] }\end{array}$ & miR-326 & lymphocytes & $\uparrow$ miR-326 \\
\hline $\begin{array}{c}\text { Salas-Pérez, } \\
\text { 2013 [57] }\end{array}$ & miR-21a + miR-93 & mononuclear cells & $\downarrow$ miR-21a + miR-93 \\
\hline $\begin{array}{c}\text { Yang, 2015 [59] } \\
\text { genome-wide }\end{array}$ & mononuclear cells & differences in 26 miRNAs \\
\hline
\end{tabular}

$\downarrow$ Decrease of miRNA expression. $\uparrow$ Increase of miRNA expression.

\section{Conclusions}

Epigenetic modifications influence pathogenesis of T1DM [63]. A better understanding of epigenetic mechanisms is necessary for identification of the target epigenetic pathways involved in the ethiopathogenesis of T1DM. Knowledge of the epigenetic changes in T1DM can help us to find potential biomarkers for prevention, diagnosis, prognosis, an d personalized treatment of the disease [64]. Lifesaving insulin therapy unfortunately does not restore the loss of pancreatic function. Epigenetic drugs may partly prevent from the destruction of $\beta$-cells.

Funding: This survey was funded by the research programme of Charles University: PROGRES Q36 Metabolism an d 260387/SVV/2019 Molecular, endocrine an d genetic aspects of diabetes mellitus etiology.

Conflicts of Interest: The authors declare no conflict of interest. 


\section{Abbreviations}

$\begin{array}{ll}\text { APC } & \text { an tigen presenting cells } \\ \text { CIITA } & \text { class II transactivator } \\ \text { COX } & \text { cyclooxygenase } \\ \text { CREBBP } & \text { cAMP-response element binding protein (CREB) binding protein } \\ \text { DNMTs } & \text { DNA-methyltransferases } \\ \text { FOXP } & \text { "forkhead box P" transcription factor } \\ \text { GAD } & \text { glutamic acid decarboxylase } \\ \text { HATs } & \text { histone-acetyltransferases } \\ \text { HDACs } & \text { histone-deacetylases } \\ \text { HLA } & \text { human leukocyte an tigen } \\ \text { HPA } & \text { hypothalamic-pituitary-adrenal } \\ \text { INS } & \text { insulin } \\ \text { LADA } & \text { latent autoimmune diabetes in adults } \\ \text { MBD } & \text { methyl-CpG-binding proteins } \\ \text { mTOR } & \text { mammalian/mechanistic target of rapamycin (serine-threonine kinase) } \\ \text { MZ twins } & \text { monozygotic twins } \\ \text { NF- } k B & \text { nuclear factor kappa B } \\ \text { NFKB1A } & \text { gene for the inhibitor of NF- } k \text { B, I } \text { B } \alpha \\ \text { NOD mice } & \text { non-obese diabetic mice } \\ \text { NRF1 } & \text { nuclear respiratory factor 1 } \\ \text { PDCD4 } & \text { programmed cell death protein 4 } \\ \text { PTPN22 } & \text { protein tyrosin-phosphatase non-receptor-type 22 } \\ \text { RFXAP } & \text { regulatory factor X associated protein } \\ \text { RISC } & \text { RNA-induced silencing complex } \\ \text { SAM } & \text { S-adenosyl methionine donor } \\ \text { SNP } & \text { single nucleotide polymorphism } \\ \text { T1DM } & \text { type 1 diabetes mellitus } \\ \text { Tregs } & \text { regulatory T cells } \\ \text { TSA } & \text { trichostatin A } \\ \text { VNTR } & \text { variable number tandem repeat } \\ & \end{array}$

\section{References}

1. Sharp, S.A.; Weedon, M.N.; Hagopian, W.A.; Oram, R.A. Clinical an d research uses of genetic risk scores in type 1 diabetes. Curr. Opin. Genet. Dev. 2018, 50, 96-102. [CrossRef]

2. Nyaga, D.M.; Vickers, M.H.; Jefferies, C.; Perry, J.K.; O'Sullivan, J.M. The genetic architecture of type 1 diabetes mellitus. Mol. Cell. Endocrinol. 2018, 477, 70-80. [CrossRef]

3. Abbas, A.K.; Lichtman, A.H.; Pillai, S. Cellular an d Molecular Immunology, 7th ed.; Elsevier Saunders: Philadelphia, PA, USA, 2012.

4. Cerna, M. Genetics of autoimmune diabetes mellitus. Wien. Med. Wochenschr. 2008, 158, 2-12. [CrossRef]

5. Rewers, M.; Ludvigsson, J. Environmental risk factors for type 1 diabetes. Lancet 2016, 387, $2340-2348$. [CrossRef]

6. Paun, A.; Yau, C.; Danska, J.S. The influence of the microbiome on type 1 diabetes. J. Immunol. 2017, 198, 590-595. [CrossRef]

7. Bach, J.F. The hygiene hypothesis in autoimmunity: The role of pathogens an $\mathrm{d}$ commensals. Nat. Rev. Immunol. 2018, 18, 105-120. [CrossRef] [PubMed]

8. Sharif, K.; Watad, A.; Coplan, L.; Amital, H.; Shoenfeld, Y.; Afek, A. Psychological stress an d type 1 diabetes mellitus: What is the link? Expert Rev. Clin. Immunol. 2018, 14, 1081-1088. [CrossRef] [PubMed]

9. Allis, C.D.; Jenuwein, T. The molecular hallmarks of epigenetic control. Nat. Rev. Genet. 2016, 17, 487-500. [CrossRef]

10. Rose, N.R.; Klose, R.J. Understanding the relationship between DNA methylation an d histone lysine methylation. Biochim. Biophys. Acta 2014, 1839, 1362-1372. [CrossRef] 
11. Garcia-Gonzalez, E.; Escamilla-Del-Arenal, M.; Arzate-Mejia, R.; Recillas-Targa, F. Chromatin remodeling effects on enhancer activity. Cell. Mol. Life Sci. 2016, 73, 2897-2910. [CrossRef] [PubMed]

12. Ruiz-Hernandez, A.; Kuo, C.-C.; Rentero-Garrido, P.; Tang, W.-Y.; Redon, J.; Ordovas, J.M.; Navas-Acien, A.; Tellez-Plaza, M. Environmental chemicals an d DNA methylation in adults: A systematic review of the epidemiologic evidence. Clin. Epigenet. 2015, 7, 55. [CrossRef] [PubMed]

13. Gaine, M.E.; Chatterjee, S.; Abel, T. Sleep deprivation an d the epigenome. Front. Neural Circuits 2018, 12, 14. [CrossRef] [PubMed]

14. Yu, G.; Wu, Q.; Gao, Y.; Chen, M.; Yang, M. The epigenetics of aging in invertebrates. Int. J. Mol. Sci. 2019, 20, 4535. [CrossRef] [PubMed]

15. Sapienza, C.; Issa, J.P. Diet, nutrition, an d cancer epigenetics. Annu. Rev. Nutr. 2016, 36, 665-681. [CrossRef] [PubMed]

16. Picascia, A.; Grimaldi, V.; Pignalosa, O.; De Pascale, M.R.; Schiano, C.; Napoli, C. Epigenetic control of autoimmune diseases: From bench to bedside. Clin. Immunol. 2015, 157, 1-15. [CrossRef] [PubMed]

17. Taudt, A.; Colomé-Tatché, M.; Johannes, F. Genetic sources of population epigenomic variation. Nat. Rev. Genet. 2016, 17, 319-332. [CrossRef]

18. Surace, A.E.A.; Hedrich, C.M. The role of epigenetics in autoimmune/inflammatory disease. Front. Immunol. 2019, 10, 1525. [CrossRef]

19. Klose, R.J.; Bird, A.P. Genomic DNA methylation: The mark an d its mediators. Trends Biochem. Sci. 2006, 31, 89-97. [CrossRef]

20. Weber, M.; Hellmann, I.; Stadler, M.B.; Ramos, L.; Pääbo, S.; Rebhan, M.; Schübeler, D. Distribution, silencing potential an d evolutionary impact of promoter DNA methylation in the human genome. Nat. Genet. 2007, 39, 457-466. [CrossRef]

21. Shen, H.; Qiu, C.; Li, J.; Tian, Q.; Deng, H.-W. Characterization of the DNA methylome an d its interindividual variation in human peripheral blood monocytes. Epigenomics 2013, 5, 255-269. [CrossRef]

22. Majumder, P.; Boss, J.M. DNA methylation dysregulates an d silences the HLA-DQ locus by altering chromatin architecture. Genes Immun. 2011, 12, 291-299. [CrossRef] [PubMed]

23. Zajacová, M. Regulation of HLA Class II Genes Expression. Ph.D. The sis, Charles University, Third Faculty of Medicine, Vinohrady, Czech Republic, 2018.

24. Xiang, Z.; Yang, Y.; Chang, C.; Lu, Q. The epigenetic mechanism for discordance of autoimmunity in monozygotic twins. J. Autoimmun. 2017, 83, 43-50. [CrossRef] [PubMed]

25. Rakyan, V.K.; Beyan, H.; Down, T.A.; Hawa, M.I.; Maslau, S.; Aden, D.; Daunay, A.; Busato, F.; Mein, C.A.; Manfras, B.; et al. Identification of type 1 diabetes-associated DNA methylation variable positions that precede disease diagnosis. PLoS Genet. 2011, 7, 1002300. [CrossRef] [PubMed]

26. Stefan, M.; Zhang, W.; Concepcion, E.; Yi, Z.; Tomer, Y. DNA methylation profiles in type 1 diabetes twins point to strong epigenetic effects on etiology. J. Autoimmun. 2014, 50, 33-37. [CrossRef] [PubMed]

27. Elboudwarej, E.; Cole, M.; Briggs, F.B.S.; Fouts, A.; Fain, P.R.; Quach, H.; Quach, D.; Sinclair, E.; Criswell, L.A.; Lane, J.A.; et al. Hypomethylation within gene promoter regions an d type 1 diabetes in discordant monozygotic twins. J. Autoimmun. 2016, 68, 23-29. [CrossRef]

28. Paul, D.; Teschendorff, A.E.; Dang, M.A.; Lowe, R.; Hawa, M.I.; Ecker, S.; Beyan, H.; Cunningham, S.; Fouts, A.R.; Ramelius, A.; et al. Increased DNA methylation variability in type 1 diabetes across three immune effector cell types. Nat. Commun. 2016, 7, 13555. [CrossRef]

29. Disanto, G.; Vcelakova, J.; Pakpoor, J.; Elangovan, R.I.; Sumnik, Z.; Ulmannova, T.; Ebers, G.C.; Ramagopalan, S.V.; Stechová, K. DNA methylation in monozygotic quadruplets affected by type 1 diabetes. Diabetologia 2013, 56, 2093-2095. [CrossRef]

30. Zajacova, M.; Kotrbova-Kozak, A.; Cepek, P.; Cerna, M. Differences in promoter DNA methylation an d mRNA expression of individual alleles of the HLA class II DQA1 gene. Immunol. Lett. 2015, 167, 147-154. [CrossRef]

31. Cepek, P.; Zajacova, M.; Kotrbova-Kozak, A.; Silhova, E.; Cerna, M. DNA methylation an d mRNA expression of HLA-DQA1 alleles in type 1 diabetes mellitus. Immunology 2016, 148, 150-159. [CrossRef]

32. Li, Y.; Zhao, M.; Hou, C.; Liang, G.; Yang, L.; Tan, Y.; Wang, Z.; Yin, H.; Zhou, Z.; Lu, Q. Abnormal DNA methylation in CD4+ T cells from people with latent autoimmune diabetes in adults. Diabetes Res. Clin. Pract. 2011, 94, 242-248. [CrossRef] 
33. Redondo, M.J.; Steck, A.K.; Pugliese, A. Genetics of type 1 diabetes. Pediatr. Diabetes 2018, 19, $346-353$. [CrossRef] [PubMed]

34. Fradin, D.; Le Fur, S.; Mille, C.; Naoui, N.; Groves, C.; Zelenika, D.; McCarthy, M.I.; Lathrop, M.; Bougnères, P. Association of the $\mathrm{CpG}$ methylation pattern of the proximal insulin gene promoter with type 1 diabetes. PLoS ONE 2012, 7, 0036278. [CrossRef] [PubMed]

35. Rui, J.; Deng, S.; Lebastchi, J.; Clark, P.L.; Usmani-Brown, S.; Herold, K.C. Methylation of insulin DNA in response to proinflammatory cytokines during the progression of autoimmune diabetes in NOD mice. Diabetologia 2016, 59, 1021-1029. [CrossRef] [PubMed]

36. Husseiny, M.I.; Kuroda, A.; Kaye, A.N.; Nair, I.; Kandeel, F.; Ferreri, K. Development of a quantitative methylation-specific polymerase chain reaction method for monitoring beta cell death in type 1 diabetes. PLoS ONE 2012, 7, 0047942. [CrossRef] [PubMed]

37. Akirav, E.M.; Lebastchi, J.; Galvan, E.M.; Henegariu, O.; Akirav, M.; Ablamunits, V.; Lizardi, P.M.; Herold, K.C. Detection of beta cell death in diabetes using differentially methylated circulating DNA. Proc. Natl. Acad. Sci. USA 2011, 108, 19018-19023. [CrossRef] [PubMed]

38. Fisher, M.M.; Watkins, R.A.; Blum, J.; Evans-Molina, C.; Chalasani, N.; DiMeglio, L.A.; Mather, K.J.; Tersey, S.A.; Mirmira, R.G. Elevations in circulating methylated an d unmethylated preproinsulin DNA in new-onset type 1 diabetes. Diabetes 2015, 64, 3867-3872. [CrossRef]

39. Olsen, J.A.; Kenna, L.A.; Spelios, M.G.; Hessner, M.J.; Akirav, E.M. Circulating differentially methylated amylin DNA as a biomarker of $\beta$-cell loss in type 1 diabetes. PLOS ONE 2016, 11, 0152662. [CrossRef]

40. Belot, M.P.; Fradin, D.; Mai, N.; Le Fur, S.; Zélénika, D.; Kerr-Conte, J.; Pattou, F.; Lucas, B.; Bougnères, P. CpG methylation changes within the IL2RA promoter in type 1 diabetes of childhood onset. PLoS ONE 2013, 8, e68093. [CrossRef]

41. Chen, B.; Sun, L.; Zhang, X. Integration of microbiome an d epigenome to decipher the pathogenesis of autoimmune diseases. J. Autoimmun. 2017, 83, 31-42. [CrossRef]

42. Knip, M.; Siljander, H. The role of the intestinal microbiota in type 1 diabetes mellitus. Nat. Rev. Endocrinol. 2016, 12, 154-167. [CrossRef]

43. Davis-Richardson, A.G.; Triplett, E.W. A model for the role of gut bacteria in the development of autoimmunity for type 1 diabetes. Diabetologia 2015, 58, 1386-1393. [CrossRef] [PubMed]

44. Gowher, H.; Jeltsch, A. Mammalian DNA methyltransferases: New discoveries an d open questions. Biochem. Soc. Trans. 2018, 46, 1191-1202. [CrossRef] [PubMed]

45. Suzuki, K.; Luo, Y. Histone acetylation an $\mathrm{d}$ the regulation of major histocompatibility class II gene expression. Adv. Protein Chem. Struct. Biol. 2017, 106, 71-111. [PubMed]

46. Miao, F.; Smith, D.D.; Zhang, L.; Min, A.; Feng, W.; Natarajan, R. Lymphocytes from patients with type 1 diabetes display a distinct profile of chromatin histone H3 lysine 9 dimethylation. Diabetes 2008, 57, 3190-3198. [CrossRef]

47. Miao, F.; Chen, Z.; Zhang, L.; Liu, Z.; Wu, X.; Yuan, Y.C.; Natarajan, R. Profiles of epigenetic histone post-translational modifications at type 1 diabetes susceptible genes. J. Biol. Chem. 2012, 287, 16335-16345. [CrossRef]

48. Miao, F.; Gonzalo, I.G.; Lanting, L.; Natarajan, R. In vivo chromatin remodeling events leading to inflammatory gene transcription under diabetic conditions. J. Biol. Chem. 2004, 279, 18091-18097. [CrossRef]

49. Miao, F.; Wu, X.; Zhang, L.; Yuan, Y.C.; Riggs, A.D.; Natarajan, R. Genome-wide an alysis of histone lysine methylation variations caused by diabetic conditions in human monocytes. J. Biol. Chem. 2007, 282, 13854-13863. [CrossRef]

50. Chen, S.S.; Jenkins, A.J.; Majewski, H. Elevated plasma prostaglandins an d acetylated histone in monocytes in type 1 diabetes patients. Diabet. Med. 2009, 26, 182-186. [CrossRef]

51. Liu, X.Y.; Xu, J.F. Reduced histone H3 acetylation in CD4+ T lymphocytes: Potential mechanism of latent autoimmune diabetes in adults. Dis. Markers 2015, 2015, 285125. [CrossRef]

52. Holoch, D.; Moazed, D. RNA-mediated epigenetic regulation of gene expression. Nat. Rev. Genet. 2015, 16, 71-84. [CrossRef]

53. Svoboda, P. Renaissance of mammalian endogenous RNAi. FEBS Lett. 2014, 588, 2550-2556. [CrossRef]

54. Hezova, R.; Slaby, O.; Faltejskova, P.; Mikulkova, Z.; Buresova, I.; Raja, M.; Hodek, J.; Ovesna, J.; Michalek, J. MicroRNA-342, microRNA-191 an d microRNA-510 are differentially expressed in T regulatory cells of type 1 diabetic patients. Cell. Immunol. 2010, 260, 70-74. [CrossRef] [PubMed] 
55. de Jong, V.M.; van der Slik, A.R.; Laban, S.; van 't Slot, R.; Koeleman, B.P.C.; Zaldumbide, A.; Roep, B.O. Survival of autoreactive T lymphocytes by microRNA-mediated regulation of apoptosis through TRAIL an d Fas in type 1 diabetes. Genes Immun. 2016, 17, 342-348. [CrossRef]

56. Sebastiani, G.; Grieco, F.A.; Spagnuolo, I.; Galleri, L.; Cataldo, D.; Dotta, F. Increased expression of microRNA miR-326 in type 1 diabetic patients with ongoing islet autoimmunity. Diabetes Metab. Res. Rev. 2011, 27, 862-866. [CrossRef]

57. Salas-Perez, F.; Codner, E.; Valencia, E.; Pizarro, C.; Carrasco, E.; Perez-Bravo, F. MicroRNAs miR-21a an d miR-93 are down regulated in peripheral blood mononuclear cells (PBMCs) from patients with type 1 diabetes. Immunobiology 2013, 218, 733-737. [CrossRef]

58. Wang, S.; Wan, X.; Ruan, Q. The microRNA-21 in autoimmune diseases. Int. J. Mol. Sci. 2016, $17,864$. [CrossRef]

59. Yang, M.; Ye, L.; Wang, B.; Gao, J.; Liu, R.; Hong, J.; Wang, W.; Gu, W.; Ning, G. Decreased miR-146 expression in peripheral blood mononuclear cells is correlated with ongoing islet autoimmunity in type 1 diabetes patients. J. Diabetes 2015, 7, 158-165. [CrossRef] [PubMed]

60. Zheng, Y.; Wang, Z.; Zhou, Z. miRNAs: Novel regulators of autoimmunity-mediated pancreatic $\beta$-cell destruction in type 1 diabetes. Cell. Mol. Immunol. 2017, 14, 488-496. [CrossRef]

61. Garo, L.P.; Murugaiyan, G. Contribution of microRNAs to autoimmune diseases. Cell. Mol. Life. Sci. 2016, 73, 2041-2051. [CrossRef]

62. Ruan, Q.; Wang, T.; Kameswaran, V.; Wei, Q.; Johnson, D.S.; Matschinsky, F.; Shi, W.; Chen, Y.H. The microRNA-21-PDCD4 axis prevents type 1 diabetes by blocking pancreatic $\beta$ cell death. Proc. Natl. Acad. Sci. USA 2011, 108, 12030-12035. [CrossRef] [PubMed]

63. Jerram, S.T.; Dang, M.N.; Leslie, R.D. The role of epigenetics in type 1 diabetes. Curr. Diabetes Rep. 2017, 17, 89. [CrossRef]

64. Zullo, A.; Sommese, L.; Nicoletti, G.; Donatelli, F.; Mancini, F.P.; Napoli, C. Epigenetics an d type 1 diabetes: Mechanisms an d translational applications. Transl. Res. 2017, 185, 85-93. [CrossRef]

(C) 2019 by the author. Licensee MDPI, Basel, Switzerland. This article is an open access article distributed under the terms and conditions of the Creative Commons Attribution (CC BY) license (http://creativecommons.org/licenses/by/4.0/). 